\title{
Tren penelitian educational game untuk peningkatan kreativitas siswa: Sebuah systematic review dari literatur
}

\author{
Novia Novia *, Anna Permanasari, Riandi Riandi, Ida Kaniawati \\ Universitas Pendidikan Indonesia. Jl. Dr. Setiabudhi No. 229 Bandung 40154, Jawa Barat - Indonesia \\ * Coressponding Author. E-mail: novia@upi.edu
}

Received: 25 November 2020; Revised: 8 December 2020; Accepted: 30 December 2020

\begin{abstract}
Abstrak: Paper ini memetakan berbagai perspektif tentang game edukasi dan pengaruhnya terhadap kreativitas serta menyatukan pemikiran terbaru di bidang ini. Tujuan utama penelitian ini adalah untuk mengetahui apakah penggunaan teknologi berupa educational game dapat meningkatkan kreativitas siswa dalam pembelajaran di kelas. Tinjauan Sistematis ini menggunakan 20 publikasi yang berasal indexed journal antara tahun 2011 hingga 2020 untuk menyoroti fokus bidang penelitian ini. Metode yang digunakan dalam penelitian ini adalah systematic review dengan pedoman Kitchenham terhadap studi penggunaan educational game untuk meningkatkan kreativitas siswa. Hasil penelitian ini menunjukkan bahwa penggunaan educational game memiliki efek aktif dalam memperkuat pemikiran kreatif siswa. Studi ini memberikan saran tentang bagaimanakah metode untuk meningkatkan kreativitas, memotivasi, dan meningkatkan hasil belajar serta mendemonstrasikan pembelajaran dengan educational game. Studi ini memberikan sebuah pandangan untuk peneliti, desainer game, pengembang di bidang educational game dan kreativitas.
\end{abstract}

Kata Kunci: Educational game, kreativitas, systematic review

\section{Research trend on the educational game to improve students' creativity: A systematic review of literature}

\begin{abstract}
This paper maps different perspectives on educational games and their impact on creativity and brings together the latest thinking in this area. The main objective of this study was to determine whether the use of technology in the form of educational games could increase student creativity in classroom learning. This Systematic Review uses 20 publications from indexed journals between 2011 and 2020 to highlight the focus of this research area. The method used in this study is a systematic review of Kitchenham's guidelines on the study of the use of educational games to increase student creativity. The results of this study indicate that the use of educational games has an active effect in strengthening students' creative thinking. This study provides suggestions on how to increase creativity, motivate, and improve learning outcomes as well as demonstrate learning with educational games. This study provides a view for researchers, game designers, developers in the fields of educational games and creativity.
\end{abstract}

Keywords: Educational game, creativity, systematic review

How to Cite: Novia, N., Permanasari, A., Riandi, R., \& Kaniawati, I. (2020). Tren penelitian educational game untuk peningkatan kreativitas siswa: Sebuah systematic review dari $\begin{array}{llll}\text { literatur. Jurnal Inovasi } & \text { Pendidikan } & \text { IPA, } & 6(2),\end{array}$ doi:https://doi.org/10.21831/jipi.v6i2.38419

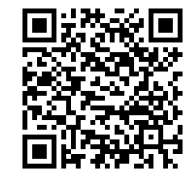

\section{PENDAHULUAN}

Kreativitas memainkan peranan penting sebagai keterampilan abad 21 yang sangat dibutuhkan oleh siswa (Alacapinar, 2013; Boltz et al., 2015; Gordeeva \& Veryaskina, 2019; Mishra, 2012). Kreativitas telah banyak didefinisikan di berbagai literatur dan dapat membantu siswa dalam mengkontruksi pengetahuan serta memberikan sudut pandang yang lebih tepat (Alfonso-Benlliure et al., 2013; Amabile, 2018; Anderson et al., n.d.). Penelitian mengenai peningkatan kreativitas dengan berbagai metode dilakukan selama beberapa dekade terakhir, termasuk dengan menggunakan educational game (Aleven et al., 2010; Annetta, 2013; Arumsari \& Sugiat, 2015; Kusmawati, 2017; Santofani \& Rosana, 2016). Banyak literatur yang telah diterbitkan mengenai educational game dalam peningkatan kreativitas bagi siswa di berbasgai tingkatan pendidikan dan domain pembelajaran (Behnamnia et al., 
Jurnal Inovasi Pendidikan IPA, 6 (2), 2020 - 218

Novia Novia, Anna Permanasari, Riandi Riandi, Ida Kaniawati

2018; Boyce et al., 2011; Supandi \& Senam, 2019; Zaki et al., 2018). Namun keadan penelitian game edukasi pada saat ini berada pada tahapan pengenalan dan aplikasi satu jenis game untuk satu atau dua keterampilan (Emamirizi et al., 2019; Girard et al., 2013; Hacker \& Kiggens, 2011).

Penelitian mengenai educational game dapat meningkatkan kreativitas siswa dilakukan oleh Bottino (2012). Studi ini menunjukkan bahwa MAGICAL (MAking Games in Collaboration for Learning) dapat meningkatkan penalaran ilmiah dan kreativitas dengan teori learning by doing. Selain itu, Cascini dkk meneliti mengenai peningkatan kreativitas pada anak usia 3-8 tahun dengan model dan postulat OTSM-TRIZ (Bottino, 2012; Cascini, 2015). Hasil penelitiannya mengungkapkan bahwa classical OTSM-TRIZ games dapat meningkatkan kretaivitas dengan experimental activities run (Bottino, 2012; Cascini, 2015).

Namun, Penelitian lebih lanjut mengungkapkan bahwa studi mengenai educational game ini masih harus terus dilanjutkan dalam upaya peningkatan kreativitas siswa di dalam kelas untuk menemukan formulasi yang tepat mengenai kesesuaian antara teori belajar yang digunakan, jenis game yang diaplikasikan dan hasil pembelajaran yang ingin dicapai (Agogué et al., 2015; Alimov et al., 2019; Apperley \& Walsh, 2012; Azizah, 2015; Girard et al., 2013; Hacker \& Kiggens, 2011). Penelitian-penelitian ini menunjukkan educational game meningkatkan kreativitas, jenis permainan, instruksi, elemen permainan dan tingkatan manakah educational game dapat meningkatkan kreativitas (Agogué et al., 2015; Arnab et al., 2019; Behnamnia et al., 2018).

Kajian yang mendalam mengenai game edukasi ini memungkinkan peneliti untuk mendapatkan suatu nilai yang unik dari lingkungan belajar yang menerapkan game edukasi sebagai medianya. Penelitian tersebut membutuhkan suatu kajian yang menyeluruh seperti systematic review. Penelitian Fardilha dan Allen (2020) menunjukkan bahwa sytematic review dapat memberikan gambaran lengkap mengenai penelitian kreativitas, mulai dari definisi, hubungan kreativitas, penilaian kreativitas dan perkembangannya.

Selain itu, Connolly et al. (2012) meneliti tentang computer game dengan systematic review. Hasil penelitiannya mengungkapkan bahwa beberapa game yang termasuk kategori computer game dianalisis dengan pendekatan multidimens (Connolly et al., 2012). Berdasarkan penelitian-penelitian tersebut, maka terlihat celah penelitian yang dapat menggabungkan hubungan antara kreativitas dengan pengembangan educational game dalam satu kajian yang sistematik. Penelitian ini bertujuan untuk memetakan berbagai perspektif tentang game edukasi dan pengaruhnya terhadap kreativitas.

\section{METODE}

Penelitian ini menggunakan analisis systematic review terhadap penggunaan educational game dalam pembelajaran untuk meningkatkan kreativitas siswa berdasarkan pedoman Kitchenham. systematic review dapat memetakan secara jelas perkembangan penelitian pada suatu tema (Angarita \& Chiappe, 2019; Chan, 2013). Systematic review menggabungkan beberapa aktivitas terpisah (Davies et al., 2014; Sawyer, 2017; van Laar et al., 2017). Tahapan systematic review terdiri dari 3 proses utama yaitu: merencanakan review, melakukan review, melaporkan (Connolly et al., 2012; Davies et al., 2014). Tahapan tersebut dapat terlihat pada Gambar 1.

Tahapan pertama untuk merencanakan review dilakukan dengan kajian analisis literatur pada penelitian-penelitian lain dan mempersiapkan jenis aplikasi yang akan digunakan sesuai kebutuhan systematic review Merencanakan pemilihan kata kunci yang tepat untuk meneliti lebih jauh mengenai educational game dan kreativitas dalah sebuah kajian literatur. Rencana pemilihan kata kunci yaitu "creativity in educational game" dengan menggunakan software tertentu untuk peningkatan kualitas kajiannya.

Tujuan Tahapan kedua dimulai dengan menentukan jenis penelitian yang dilakukan yaitu systematic review of literature. Metode ini bertujuan agar penelitian ini dapat memberikan gambaran dari kajian literatur yang lebih komprehensif berdasarkan tema penelitian sehingga dapat memberikan gambaran bari penelitian-penelitian selanjutnya. Paper yang digunakan untuk kajian ini adakah kumpulan dari database online, seperti Science Direct, Springer, Wiley dalam bentuk artikel jurnal, prosiding dan book chapter. Pencarian database dilakukan dengan menggunakan aplikasi publish or perish dengan pilihan sumber pencarian yang berasal dari scopus. Hal ini dimaksudkan agar pencarian data dapat dilakukan dengan lebih menyeluruh. Aplikasi publish or perish ini dapat menyajikan data yang lebih banyak dan lebih detail sesuai dengan kata kunci sehingga pencarian lebih berkualitas. 
Jurnal Inovasi Pendidikan IPA, 6 (2), 2020 - 219

Novia Novia, Anna Permanasari, Riandi Riandi, Ida Kaniawati

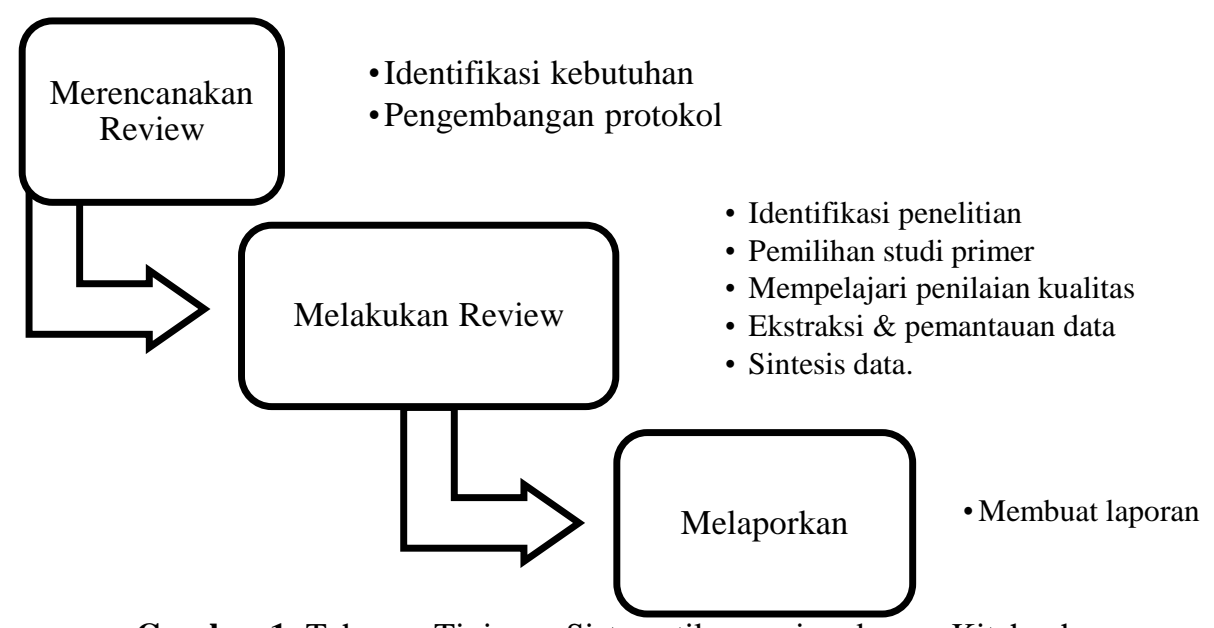

Gambar 1. Tahapan Tinjauan Sistematik sesuai pedoman Kitchenham

Hasil pencarian pada publish of perish dari data scopus yang berhubungan dengan adanya luaran kreativitas dengan adanya penggunaan educational game adalah 50. Data ini kemudian disortir dan dibaca satu persatu untuk kemudian dipilih bedasarkan kata kunci dan abstrak menjadi 20 artikel. Setelah membaca judul dan abstrak dari 20 artikel terkait dengan penggunaan educational game dan kreativitas, paper tersebut kemudian dibaca secara menyeluruh dengan tujuan utama mencari tahu secara umum. Langkah selanjutnya adalah memetakan penelitian yang telah dilakukan pada topik ini.

Artikel yang terpilih dalam ulasan ini harus memiliki kriteria berupa topik tentang; (1) Penggunaan educational game untuk peningktaran kreativitas pada pembelajaran; (2) Menggunakan metode kualitatif dan kuantitatif; (3) Berfokus pada jenis game, learning theory, platform yang digunakan serta learning outcome; (4) Artikel-artikel ini diberi tanggal dari 2011 hingga 2020.

\section{HASIL DAN PEMBAHASAN}

Bagian ini akan menyajikan berbagai hasil penelitian berserta pembahasannya. Kajian sistematis pada berbagai publikasi memberikan gambaran umum mengenai hubungan yang erat antara educational game dengan kreativitas dengan berbagai desain penelitian yang dilakukan. Hasil literature review dari 20 penelitian ini menunjukkan bahwa 6 penelitian menggunakan mixed method (30\%), 4 penelitian menggunakan desain eksperimental (20\%), dua penelitian menggunakan metode studi kasus (10\%), 2 penelitian menggunakan menggunakan metode deskriptif (10\%). Penelitian lain ada yang menggunakan metode $\mathrm{RnD}$, metode MAGICAL project, series pilot session, dan observasi.

Tinjauan pada jenis sumber dokumen yang digunakan menunjukkan bahwa $60 \%$ berasal dari jurnal, $35 \%$ berasal dari prosiding konferensi dan 5\% berasal dari book chapter. Hasil ini menunjukkan bahwa penelitian-penelitian berasal dari jurnal dan memiliki fokus yang cukup besar pada jenis penelitian mixed method. Hasil penelitian ini sejalan dengan penelitian Fessakis (2015); Pellas et al. (2017); dan Pinder (2018).

Hubungan antara penggunaan game dan kreativitas tidak hanya dilihat berdasarkan keseluruhan hasil pencapaian baik berdasarkan hasil perhitungan statistik (misalnya $n$-gain atau effect size) tetapi dapat dilihat berdasarkan komponen-komponen dalam susunan artikelnya (Annetta, 2013; Emamirizi et al., 2019). Penelitian ini memilih hubungan antara penulis, jenis sumber artikel, metode yang digunakan pada artikel, tingkat pendidikan yang dipilih (subjek penelitian/partisipan), platform yang digunakan, dukungan instruksional, elemen pada elemen desain gamenya, jenis game, teori yang digunakan, fokus penelitian dan capaian pembelajaran. Overview mengenai berbagai hubungan ini dapat dilihat pada Tabel 1.

Overview berdasarkan Tabel 1 menunjukkan hubungan antar variabel yang diteliti secara umum mengenai adanya peningkatan kreativitas berdasarkan penggunaan educational game. Selanjutnya, studi literatur ini mengkaji overview secara spesifik mengenai tingkatan pendidikan atau usia yang menjadi target penelitian, teori yang dominan digunakan serta capaian pembelajaran yang diharapkan. Overview tersebut dapat dilihat pada Tabel 2, Tabel 3 dan Tabel 4. 
Jurnal Inovasi Pendidikan IPA, 6 (2), 2020 - 220

Novia Novia, Anna Permanasari, Riandi Riandi, Ida Kaniawati

Tabel 1. Overview Hubungan Artikel Ilmiah mengenai Penggunaan Educational Game dalam Peningkatan Kreativitas

\begin{tabular}{|c|c|c|c|c|c|c|c|c|c|c|}
\hline Penulis & $\begin{array}{c}\text { Jenis } \\
\text { Sumber }\end{array}$ & Metode & $\begin{array}{l}\text { Tingkatan } \\
\text { Pendidikan }\end{array}$ & Platform & $\begin{array}{c}\text { Dukungan } \\
\text { Instruksional }\end{array}$ & Elemen Desain & Jenis Game & Teori & Focus Penelitian & Capaian Pembelajaran \\
\hline Bottino et al. & Prosiding & $\begin{array}{l}\text { Pengembangan } \\
\text { MAGICAL } \\
\text { MAking Games } \\
\text { In CollaborAtion } \\
\text { for Learning } \\
\text { project }\end{array}$ & Sekolah Dasar & Digital game & $\begin{array}{l}\text { Pengalaman } \\
\text { hands-on }\end{array}$ & $\begin{array}{l}\text { Pendekatan digital } \\
\text { game- based open } \\
\text { environment and a } \\
\text { collaborative }\end{array}$ & $\begin{array}{l}\text { Massive } \\
\text { Multiplayer } \\
\text { Online Role- } \\
\text { Playing Games) }\end{array}$ & $\begin{array}{l}\text { Konstruktivisme } \\
\text { sosial }\end{array}$ & $\begin{array}{l}\text { Membangun } \\
\text { pengetahuan sendiri, } \\
\text { kesulitan belajar dan } \\
\text { proses "programming" }\end{array}$ & $\begin{array}{l}\text { Kreativitas, kemampuan } \\
\text { penalaran dan logis, } \\
\text { Kompetensi digital }\end{array}$ \\
\hline Boysen et al. & Jurnal & $\begin{array}{l}\text { mixed methods } \\
\text { comparative } \\
\text { study dan } \\
\text { metodologi semi- } \\
\text { experimental }\end{array}$ & $\begin{array}{l}\text { Pendidikan } \\
\text { tinggi }\end{array}$ & Digital game & $\begin{array}{l}\text { Desain } \\
\text { Pendekatan } a \\
\text { pass-the-baton } \\
\text { design }\end{array}$ & collaborative work & $\begin{array}{l}\text { educational } \\
\text { games }\end{array}$ & $\begin{array}{l}\text { Teori motivasi } \\
\text { intrinsik and } \\
\text { extrinsik }\end{array}$ & Luaran kreatif & $\begin{array}{l}\text { Berpikir fleksibel dan } \\
\text { kreativitas dalam proses } \\
\text { kolaborasi }\end{array}$ \\
\hline Cascini, et al. & Jurnal & experimental & $\begin{array}{l}\text { Usia anak 3-8 } \\
\text { tahun }\end{array}$ & $\begin{array}{l}\text { classical OTSM- } \\
\text { TRIZ games }\end{array}$ & $\begin{array}{l}\text { Ditantang melalui } \\
\text { tugas dan situasi } \\
\text { tak terduga }\end{array}$ & $\begin{array}{l}\text { Stimulasi } \\
\text { kreativitas rekayasa }\end{array}$ & logic of games & $\begin{array}{l}\text { OTSM-TRIZ } \\
\text { postulates and } \\
\text { models }\end{array}$ & Asesmen pendahuluan & Krativitas \\
\hline $\begin{array}{l}\text { Checa-Romero } \\
\text { et al. }\end{array}$ & Jurnal & $\begin{array}{l}\text { Wokshop } \\
\text { pedagagogi dan } \\
\text { intervensi } \\
\text { langsung }\end{array}$ & $\begin{array}{l}\text { Remaja berusia } \\
12-15 \text { tahun }\end{array}$ & $\begin{array}{l}\text { Digital video } \\
\text { game }\end{array}$ & $\begin{array}{l}\text { Workshop } \\
\text { delapan sesi }\end{array}$ & $\begin{array}{l}\text { Kebebasan total } \\
\text { untuk melakukan } \\
\text { kegiatan dalam } \\
\text { eksperimen }\end{array}$ & $\begin{array}{l}\text { video game } \\
\text { Minecraft }\end{array}$ & Konstruktivisme & $\begin{array}{l}\text { Analisis kreativitas } \\
\text { menggunakan tes CREA } \\
\text { dan analisis audiovisual } \\
\text { machinima products } \\
\text { yang dibuat siswa }\end{array}$ & Kreativitas \\
\hline Danahy, et al. & Jurnal & $\begin{array}{l}\text { Beberapa Studi } \\
\text { kasus }\end{array}$ & $\begin{array}{l}\text { K-12 age } \\
\text { learners, both in } \\
\text { school and in } \\
\text { informal } \\
\text { environments. }\end{array}$ & $\begin{array}{l}\text { robotic } \\
\text { platforms }\end{array}$ & LEGO curriculum & $\begin{array}{l}\text { video game } \\
\text { interaktif }\end{array}$ & $\begin{array}{l}\text { NXT and } \\
\text { LabVIEW } \\
\text { prototype }\end{array}$ & Konstruktivisme & $\begin{array}{l}\text { evaluation research in } \\
\text { engineering education }\end{array}$ & $\begin{array}{l}\text { student creativity and } \\
\text { innovation }\end{array}$ \\
\hline $\begin{array}{l}\text { Dele-Ajayi, et } \\
\text { al. }\end{array}$ & Prosiding & $\begin{array}{l}\text { Pendekatan } \\
\text { mixed methods }\end{array}$ & $\begin{array}{l}\text { Sekolah dasar } \\
\text { tingkat } 4 \text { dan } 5 \\
\text { (usia 8-11 } \\
\text { tahun) }\end{array}$ & Digital games & $\begin{array}{l}\text { Kerangka kerja } \\
\text { keterlibatan game } \\
\text { untuk menyajikan } \\
\text { komponen alat } \\
\text { Diamond } 9\end{array}$ & $\begin{array}{l}\text { inclusive digital } \\
\text { educational games }\end{array}$ & $\begin{array}{l}\text { the stereotypical } \\
\text { video game }\end{array}$ & $\begin{array}{l}\text { Konstruktivisme } \\
\text { sosial }\end{array}$ & $\begin{array}{l}\text { pria dan wanita memberi } \\
\text { peringkat penghargaan } \\
\text { sebagai faktor } \\
\text { keterlibatan paling } \\
\text { penting dalam } \\
\text { permainan }\end{array}$ & $\begin{array}{l}\text { kejelasan tujuan; daya } \\
\text { tarik tematik, daya tarik } \\
\text { visual, penghargaan, } \\
\text { umpan balik, interaksi } \\
\text { sosial; kreativitas; } \\
\text { tantangan; }\end{array}$ \\
\hline Despeisse, $\mathrm{M}$. & Prosiding & $\begin{array}{l}\text { a series of pilot } \\
\text { sessions }\end{array}$ & $\begin{array}{l}\text { siswa (dalam } \\
\text { pendidikan } \\
\text { tinggi) dan } \\
\text { peserta pelatihan } \\
\text { (dalam kursus } \\
\text { profesional) }\end{array}$ & $\begin{array}{l}\text { Classical board } \\
\text { game }\end{array}$ & $\begin{array}{l}\text { existing } \\
\text { cooperative } \\
\text { board game }\end{array}$ & $\begin{array}{l}\text { permainan kartu } \\
\text { yang lebih } \\
\text { sederhana yang } \\
\text { berfokus pada } \\
\text { praktik yang baik } \\
\text { untuk efisiensi } \\
\text { energi dalam } \\
\text { operasi manufaktur }\end{array}$ & $\begin{array}{l}\text { strategic board } \\
\text { game }\end{array}$ & $\begin{array}{l}\text { pendekatan } \\
\text { partisipatif yang } \\
\text { berpusat pada } \\
\text { siswa }\end{array}$ & $\begin{array}{l}\text { Pola pikir kreatif dan } \\
\text { inovatif }\end{array}$ & $\begin{array}{l}\text { kolaborasi, dialog, } \\
\text { pemikiran strategis, } \\
\text { skenario membayangkan, } \\
\text { pengambilan keputusan, } \\
\text { dan refleksi }\end{array}$ \\
\hline Duncan & Jurnal & $\begin{array}{l}\text { mixed-methods } \\
\text { study }\end{array}$ & $\begin{array}{l}76 \text { siswa kelas } 3 \\
\text { dari empat kelas } \\
\text { wali kelas }\end{array}$ & Digital GBL & $\begin{array}{l}\text { immersive game- } \\
\text { based } \\
\text { instructional } \\
\text { strategy }\end{array}$ & $\begin{array}{l}\text { keterlibatan } \\
\text { perilaku bervariasi } \\
\text { dari game ke game }\end{array}$ & $\begin{array}{l}\text { BOEDU } \\
\text { strategies }\end{array}$ & $\begin{array}{l}\text { self- } \\
\text { determination } \\
\text { theory }\end{array}$ & $\begin{array}{l}\text { Keterampilan belajar } \\
\text { abad } 21\end{array}$ & $\begin{array}{l}\text { collaboration, } \\
\text { communication, creativity } \\
\text { and critical thinking }\end{array}$ \\
\hline Earp, et al. & Jurnal & $\begin{array}{l}\text { The investigation } \\
\text { draws }\end{array}$ & Sekolah Dasar & Digital GBL & $\begin{array}{l}\text { instructionist- } \\
\text { style "talk \& } \\
\text { chalk" lecturing }\end{array}$ & $\begin{array}{l}\text { Kodu's visual } \\
\text { programming } \\
\text { library }\end{array}$ & $\begin{array}{l}\text { MAGICAL } \\
\text { (MAking Games } \\
\text { in CollaborAtion }\end{array}$ & Konstruktivisme & $\begin{array}{l}\text { mengaktifkan } \\
\text { keterampilan transversal } \\
\text { utama }\end{array}$ & $\begin{array}{l}\text { pemecahan masalah, } \\
\text { kreativitas dan } \\
\text { kompetensi TIK }\end{array}$ \\
\hline
\end{tabular}


Jurnal Inovasi Pendidikan IPA, 6 (2), 2020 - 221

Novia Novia, Anna Permanasari, Riandi Riandi, Ida Kaniawati

\begin{tabular}{|c|c|c|c|c|c|c|c|c|c|c|}
\hline Penulis & $\begin{array}{c}\text { Jenis } \\
\text { Sumber }\end{array}$ & Metode & $\begin{array}{c}\text { Tingkatan } \\
\text { Pendidikan } \\
\end{array}$ & Platform & $\begin{array}{c}\text { Dukungan } \\
\text { Instruksional }\end{array}$ & Elemen Desain & Jenis Game & Teori & Focus Penelitian & Capaian Pembelajaran \\
\hline $\begin{array}{l}\text { Fabricatore and } \\
\text { López. }\end{array}$ & Jurnal & Mixed method & $\begin{array}{l}\text { Rentang usia } \\
\text { antara } 19 \text { dan } \\
32\end{array}$ & $\begin{array}{l}\text { Digital video } \\
\text { game }\end{array}$ & $\begin{array}{l}\text { Pengembangan } \\
\text { projek mimicking } \\
\text { real-world } \\
\text { dynamics } \\
\text { recreated } \\
\text { contextual } \\
\text { conditions }\end{array}$ & Elemen lingkungan & $\begin{array}{l}\text { for Learning) } \\
\text { project } \\
\text { educational video } \\
\text { game }\end{array}$ & & contextual creativity & Proses kreatif \\
\hline Fessakis et al. & Jurnal & $\begin{array}{l}\text { Mixed method } \\
\text { case study }\end{array}$ & $\begin{array}{l}\text { Taman Kanak- } \\
\text { kanak }\end{array}$ & Digital game & $\begin{array}{l}\text { Kerangka specific } \\
\text { learning } \\
\text { intervention }\end{array}$ & $\begin{array}{l}\text { verifikasi kegiatan } \\
\text { belajar yang sesuai } \\
\text { perkembangan, } \\
\text { efektif, dan efisien }\end{array}$ & ICT video game & $\begin{array}{l}\text { Konstruktivisme } \\
\text { sosial }\end{array}$ & $\begin{array}{l}\text { observasi interaksi anak- } \\
\text { anak dengan perangkat } \\
\text { lunak }\end{array}$ & $\begin{array}{l}\text { kreativitas anak taman } \\
\text { kanak-kanak }\end{array}$ \\
\hline Hauge, et al. & & Studi Kasus & $\begin{array}{l}24 \text { mahasiswa } \\
\text { magister }\end{array}$ & $\begin{array}{l}\text { Digital Student } \\
\text { lab }\end{array}$ & $\begin{array}{l}\text { pengumpulan } \\
\text { pengetahuan aktif } \\
\text { tentang metode } \\
\text { kreativitas }\end{array}$ & $\begin{array}{l}\text { dua metode } \\
\text { kreativitas klasik } \\
\text { (brainstorming dan } \\
\text { brainwriting } \\
\text { dengan metode 6-3- } \\
\text { 5) }\end{array}$ & $\begin{array}{l}\text { two games } \\
\text { (refQuest and } \\
\text { theTakeover) }\end{array}$ & Konstruktivisme & $\begin{array}{l}\text { permainan yang } \\
\text { digunakan untuk } \\
\text { merangsang proses } \\
\text { berpikir kreatif }\end{array}$ & Kreativitas \\
\hline $\begin{array}{l}\text { Karabulut and } \\
\text { Oral. }\end{array}$ & Jurnal & Experimental & $\begin{array}{l}\text { Anak-anak } \\
\text { berusia } 4 \text { and } 5\end{array}$ & Digital game & $\begin{array}{l}\text { bimbingan guru, } \\
\text { program game } \\
\text { edukasi yang } \\
\text { teratur dan } \\
\text { terencana }\end{array}$ & $\begin{array}{l}\text { Thinking Creatively } \\
\text { in Action and } \\
\text { Movement (TCAM) } \\
\text { Test }\end{array}$ & $\begin{array}{l}\text { educational game } \\
\text { training }\end{array}$ & Konstruktivisme & $\begin{array}{l}\text { program game edukasi } \\
\text { yang terencana dengan } \\
\text { baik }\end{array}$ & $\begin{array}{l}\text { keterampilan berpikir } \\
\text { kreatif anak-anak }\end{array}$ \\
\hline $\begin{array}{l}\text { Koulouris and } \\
\text { Dimaraki. }\end{array}$ & Prosiding & Experimental & $\begin{array}{l}\text { Pendidik dan } \\
\text { siswa }\end{array}$ & Digital game & $\begin{array}{l}\text { collaborative } \\
\text { learning, } \\
\text { computer-assisted } \\
\text { instruction }\end{array}$ & C2Learn game & $\begin{array}{l}\text { playful digital } \\
\text { experiences }\end{array}$ & $\begin{array}{l}\text { Teori Co- } \\
\text { creativity } \\
\text { assessment }\end{array}$ & $\begin{array}{l}\text { Co-creativity, co- } \\
\text { creative thinking, digital } \\
\text { games, educational } \\
\text { scenarios, school- } \\
\text { community-centred co- } \\
\text { design }\end{array}$ & $\begin{array}{l}\text { collaborative and } \\
\text { communal creative } \\
\text { processes in gameful } \\
\text { learning contexts }\end{array}$ \\
\hline Lane and Yi. & $\begin{array}{l}\text { Book } \\
\text { Chapter }\end{array}$ & $\begin{array}{l}\text { Research and } \\
\text { development }\end{array}$ & Anak-anak & $\begin{array}{l}\text { Digital video } \\
\text { game }\end{array}$ & $\begin{array}{l}\text { ide-ide hebat di } \\
\text { STEM }\end{array}$ & $\begin{array}{l}\text { Minecraft } \\
\text { experience }\end{array}$ & $\begin{array}{l}\text { Video games of } \\
\text { this generation: } \\
\text { Minecraft. }\end{array}$ & $\begin{array}{l}\text { Konstruktivisme } \\
\text { sosial }\end{array}$ & $\begin{array}{l}\text { berbagai keterampilan } \\
\text { dan pengetahuan yang } \\
\text { relevan dengan sekolah } \\
\text { dan dunia nyata }\end{array}$ & $\begin{array}{l}\text { Pembelajaran kolaboratif } \\
\text { dan kreativitas }\end{array}$ \\
\hline Lin and Lin. & Jornal & Mix method & $\begin{array}{l}\text { Berbagai } \\
\text { jurusan dan } \\
\text { jenjang } \\
\text { pendidikan yang } \\
\text { berbeda }\end{array}$ & Digital game & $\begin{array}{l}\text { atribut permainan } \\
\text { dan nilai pribadi }\end{array}$ & $\begin{array}{l}\text { Pembangunan kota } \\
\text { simulasi, Menjadi } \\
\text { walikota, } \\
\text { Menawarkan } \\
\text { insiden bencana } \\
\text { simulasi dan } \\
\text { gambaran umum } \\
\text { Tabel informasi }\end{array}$ & SimCity's game & $\begin{array}{l}\text { Teori means-end } \\
\text { chain }\end{array}$ & $\begin{array}{l}\text { peningkatan dan strategi } \\
\text { pengajaran untuk } \\
\text { pengembang dan } \\
\text { pendidikan game digital }\end{array}$ & $\begin{array}{l}\text { imagination and } \\
\text { creativity, problem- } \\
\text { solving ability, sense of } \\
\text { responsibility, planning } \\
\text { experience, } \\
\text { organizational thinking, } \\
\text { leadership decision- } \\
\text { making and control ability } \\
\text { such as Sense of } \\
\text { achievement, Fun and } \\
\text { enjoyment of life, Self- } \\
\text { fulfillment and Self- } \\
\text { respect }\end{array}$ \\
\hline
\end{tabular}


Jurnal Inovasi Pendidikan IPA, 6 (2), 2020 - 222

Novia Novia, Anna Permanasari, Riandi Riandi, Ida Kaniawati

\begin{tabular}{|c|c|c|c|c|c|c|c|c|c|c|}
\hline Penulis & $\begin{array}{c}\text { Jenis } \\
\text { Sumber }\end{array}$ & Metode & $\begin{array}{l}\text { Tingkatan } \\
\text { Pendidikan }\end{array}$ & Platform & $\begin{array}{c}\text { Dukungan } \\
\text { Instruksional }\end{array}$ & Elemen Desain & Jenis Game & Teori & Focus Penelitian & Capaian Pembelajaran \\
\hline $\begin{array}{l}\text { López and } \\
\text { Fabricatore. }\end{array}$ & Prosiding & $\begin{array}{l}\text { Descriptive } \\
\text { research }\end{array}$ & $\begin{array}{l}\text { Rentang usia } \\
\text { antara } 19 \text { and } 32\end{array}$ & $\begin{array}{l}\text { Digital video } \\
\text { game }\end{array}$ & $\begin{array}{l}\text { developing video } \\
\text { games creates an } \\
\text { exceptional } \\
\text { setting }\end{array}$ & Contextual and task & $\begin{array}{l}\text { Video game } \\
\text { development }\end{array}$ & Konstruktivisme & $\begin{array}{l}\text { Pendekatan yang } \\
\text { menguntungkan } \\
\text { pengembangan } \\
\text { kreativitas }\end{array}$ & $\begin{array}{l}\text { Tingkatan Kreativitas } \\
\text { Individu }\end{array}$ \\
\hline $\begin{array}{l}\text { Puspitaningrum, } \\
\text { et al. }\end{array}$ & Jurnal & $\begin{array}{l}\text { Descriptive } \\
\text { research }\end{array}$ & $\begin{array}{l}\text { Siswa Sekolah } \\
\text { dasar }\end{array}$ & Classical game & $\begin{array}{l}\text { Bermain dengan } \\
\text { origami }\end{array}$ & $\begin{array}{l}\text { Aktivitas } \\
\text { independent dan } \\
\text { dependent }\end{array}$ & $\begin{array}{l}\text { Educative game } \\
\text { tools (Puzzle } \\
\text { game and } \\
\text { origami) }\end{array}$ & Konstruktivisme & $\begin{array}{l}\text { learn to hone and } \\
\text { improve their ability to } \\
\text { solve problems }\end{array}$ & Anak kreatif \\
\hline Sin, et al. & Journal & $\begin{array}{l}\text { Experimental } \\
\text { nature }\end{array}$ & $\begin{array}{l}\text { Primary and } \\
\text { secondary } \\
\text { schools }\end{array}$ & $\begin{array}{l}\text { Digital } \\
\text { experimentation } \\
\text { platform }\end{array}$ & $\begin{array}{l}\text { Cara baru untuk } \\
\text { merevitalisasi } \\
\text { marching cubes, } \\
\text { algoritma } \\
\text { penghasil mesh }\end{array}$ & $\begin{array}{l}\text { Planetary } \\
\text { Marching Cubes } \\
\text { (PMC) and Hello } \\
\text { Planet }\end{array}$ & $\begin{array}{l}\text { STEM sandbox } \\
\text { game-based } \\
\text { learning video } \\
\text { games }\end{array}$ & $\begin{array}{l}\text { Konstruktivisme } \\
\text { Sosial }\end{array}$ & $\begin{array}{l}\text { Simulasi realism, } \\
\text { creativity and } \\
\text { interactivity }\end{array}$ & $\begin{array}{l}\text { Kreativitas dan } \\
\text { Interaktivitas }\end{array}$ \\
\hline $\begin{array}{l}\text { Wang and } \\
\text { Huang. }\end{array}$ & Prosiding & Observations & $\begin{array}{l}\text { Residents or } \\
\text { visitors to that } \\
\text { place }\end{array}$ & $\begin{array}{l}\text { Mobile game } \\
\text { app }\end{array}$ & $\begin{array}{l}\text { aplikasi akan ada } \\
\text { di layar seluler }\end{array}$ & $\begin{array}{l}\text { innovative concept } \\
\text { for Smart City }\end{array}$ & $\begin{array}{l}\text { Board game is } \\
\text { being developed } \\
\text { with augmented } \\
\text { reality, RFID and } \\
\text { mobile app: The } \\
\text { "good life" }\end{array}$ & Konstruktivisme & $\begin{array}{l}\text { Mengamati perilaku } \\
\text { pengguna dalam } \\
\text { menerapkan permainan } \\
\text { papan di sudut Taipei } \\
\text { Tech University, sebagai } \\
\text { ruang publik yang } \\
\text { membantu memberikan } \\
\text { panduan perjalanan dan } \\
\text { pengenalan distrik } \\
\text { bersejarah lainnya. }\end{array}$ & $\begin{array}{l}\text { Kreativitas dalam } \\
\text { pendidikan dan sejarah }\end{array}$ \\
\hline
\end{tabular}


Jurnal Inovasi Pendidikan IPA, 6 (2), 2020 - 223

Novia Novia, Anna Permanasari, Riandi Riandi, Ida Kaniawati

Tabel 2. Target Tingkatan Pendidikan pada Penggunaan Educational Game untuk Kreativitas

\begin{tabular}{lc}
\hline \multicolumn{1}{c}{ Tingkatan Pendidikan/ Usia } & Frekuensi \\
\hline Sekolah Dasar & 3 \\
Pendidikan Tinggi & 1 \\
Anak berusia 3-8 tahun & 1 \\
Remaja berusaia 12 - 15 tahun & 1 \\
K-12 age learners, both in school and in informal environments. & 1 \\
Sekolah dasar tingkat 4 and 5 (usia 8-11 tahun) & 1 \\
Siswa (pendidikan Tinggi) and Pelatih (pada Kusus profesional) & 1 \\
76 siswa kelas 3 dari empat kelas wali kelas & 1 \\
Anak-anak TK & 1 \\
Rentang usia antara 19 dan 32 & 2 \\
24 mahasiswa magister & 1 \\
Anak usia 4 dan5 & 1 \\
Pendidik dan siswa & 1 \\
Anak-anak & 1 \\
Berbagai jurusan dan jenjang pendidikan yang berbeda & 1 \\
Primary and secondary schools & 1 \\
Residents or visitors to that place & 1 \\
\hline
\end{tabular}

Analisis lebih lanjut mengenai tingkatan pendidikan dalam penggunaan educational game untuk peningkatan kreativitas menunjukan beragam subjek atau partisipan yang ditargetkan. Hasil kajian menunjukkan bahwa penggunaan educational game paling dominan dilakukan di sekolah dasar (30\%), selanjutnya subjek atau partisipan yang berusia 19 dan 32 sebanyak $10 \%$, dan tingkatan pendidikan lain sebanyak 5\% yaitu mulai dari taman kanak-kanak hingga level pendidikan magister.

Tabel 3. Teori yang Dominan Digunakan pada Penggunaan Educational Game untuk Kreativitas

\begin{tabular}{lc}
\hline \multicolumn{1}{c}{ Tingkatan Pendidikan/ Usia } & Frekuensi \\
\hline Konstruktivisme & 9 \\
Konstruktivisme Sosial & 5 \\
Teori Motivasi intrinsik and extrinsik & 1 \\
OTSM-TRIZ postulates & 1 \\
Student-centred and participative approach & 1 \\
Self-determination theory & 1 \\
Means-end chain theory & 1 \\
Co-creativity assessment theory & 1 \\
\hline
\end{tabular}

Kajian yang sistematik ini dapat juga memberikan gambaran yang lebih rinci mengenai teori yang digunakan dalam penggunaan educaional game. Sebanyak sembilan artikel menggunakan teori konstruktivisme dalam penelitiannnya (45\%). Teori konstruktivisme sosial juga digunakan oleh 5 artikel atau $45 \%$ dari keseluruhan penelitian yang dikaji. Penelitian lain yang menggunakan teori selain konstruktivisme dan konstruktivisme sosial masing-masing 1 artikel atau 5\%.

Bukti bahwa penggunaan educational game dapat meningkatkan kreativitas dapat dilihat berdasarkan Tabel 4. Kajian pada 20 artikel tersebut menunjukkan bahwa 25\% capaian pembelajaran hanya berfokus pada kreativitas. Selebihnya, capaian pembelajaran berfokus pada berbagai keterampilan lain yang dapat ditingkatkan seiring dengan peningkatan kreativitas. Capaian pembeajaran tersebut diantaranya proses kreatif, kolaborasi, pemecahan masalah, kompetensi teknologi informasi dan komunikasi, pengambilan keputusan, interaktivitas, inovasi, self respect secara individual, perasaan fun dan enjoy, pengalaman merencanakan, pemecahan masalah khusus digital game, berpikir strategi, membut skenario, interaksi sosial dan lain sebagainya. Keterampilan berpikir kreatif juga menjadi capaian pembelajaran dalam kajian tersebut sebanyak $10 \%$.

Overview pada berbagai aspek seperti pada Tabel 2 menunjukkan bahwa kajian sistematik ini dapat menjadi rujukan untuk penelitian selanjutnya mengenai educational game. Peneliti lain dapat memilih jenis game yang telah digunakan ataupun mengembangkan game yang sudah digunakan. Teori, level pendidikan, elemen game, fokus penelitian ataupun aspek lain yang dapat dikembengkan lebih lanjut untuk pengembangan berbagai penelitian mengenai educational game. 
Jurnal Inovasi Pendidikan IPA, 6 (2), 2020 - 224

Novia Novia, Anna Permanasari, Riandi Riandi, Ida Kaniawati

Tabel 4. Capaian Pembelajaran yang Diharapkan pada Penggunaan Educational Game untuk Kreativitas

\begin{tabular}{|c|c|}
\hline Capaian Pembelajaran & Frekuensi \\
\hline Kreativitas & 5 \\
\hline $\begin{array}{l}\text { Imagination and creativity, problem-solving ability, sense of responsibility, Increase planning } \\
\text { experience, Cultivate organizational thinking, Strengthen leadership decision-making and Improve } \\
\text { control ability in their pursuit of values such as Sense of achievement, Fun and enjoyment of life, } \\
\text { Self-fulfillment and Self-respect }\end{array}$ & 1 \\
\hline Pembelajaran Kolaboratif dan Kreativitas & 1 \\
\hline Proses Kreatif Komunal dan Kolaboratif & 1 \\
\hline Berpikir Kreatif & 2 \\
\hline Kreativitas, kemampuan penalaran dan logis & 1 \\
\hline Kreativitas dan Inovasi & 1 \\
\hline $\begin{array}{l}\text { Clarity of goal; thematic appeal, visual appeal, rewards, feedback, social interaction; creativity; } \\
\text { challenge; and immersion }\end{array}$ & 1 \\
\hline $\begin{array}{l}\text { Collaboration, dialogue, strategic thinking, envisioning scenarios, decision-making in uncertain } \\
\text { conditions, and reflection }\end{array}$ & 1 \\
\hline Learning skills of collaboration, communication, creativity and critical thinking & 1 \\
\hline Pemecahan masalah, kreativitas dan kompetensi TIK & \\
\hline Proses Kreatif & \\
\hline $\begin{array}{l}\text { Imagination and creativity, problem-solving ability, Strengthen sense of responsibility, planning } \\
\text { experience, organizational thinking, leadership decision-making and control ability in their pursuit } \\
\text { of values such as Sense of achievement, Fun and enjoyment of life, Self-fulfillment and Self-respect }\end{array}$ & 1 \\
\hline Kreativitas dan interaktifitas & 1 \\
\hline
\end{tabular}

\section{SIMPULAN}

Penelitian ini meyajikan tinjauan yang sistematis mengenai tren penggunaan educational game untuk meningkatkan kreativitas siswa. Studi ini menunjukkan bahwa publikasi mengenai educational game dan kreativitas sebagian besar dilakukan di tingkat sekolah dasar sementara teori yang dominan digunakan adalah teori konstruktivisme. Diperlukan lebih banyak penelitian empiris untuk melihat sejauhmana educational game dapat dirancang untuk meningkatkan kreativitas siswa. Ini dapat menjadi rujukan peneliti lain agar dapat menemukan kelebihan dan kekurangan educational game dalam penggunaannya untuk berbagai keterampilan abad ke-21.

\section{DAFTAR PUSTAKA}

Agogué, M., Levillain, K., \& Hooge, S. (2015). Gamification of creativity: Exploring the usefulness of serious games for ideation. Creativity and Innovation ..., Query date: 2020-11-06 05:22:56. https://onlinelibrary.wiley.com/doi/abs/10.1111/caim.12138

Alacapinar, F. (2013). Grade Level and Creativity. Eurasian Journal of Educational Research, Query date: 2020-11-06 05:22:56. https://eric.ed.gov/?id=EJ1059915

Aleven, V., Myers, E., Easterday, M., \& ... (2010). Toward a framework for the analysis and design of educational games. ... Game and Intelligent Toy ..., Query date: 2020-11-06 05:22:56. https://ieeexplore.ieee.org/abstract/document/5463744/

Alfonso-Benlliure, V., Meléndez, J., \& ... (2013). Evaluation of a creativity intervention program for preschoolers. ... Skills and Creativity, Query date: 2020-11-06 05:22:56. https://www.sciencedirect.com/science/article/pii/S1871187113000497

Alimov, A., Shabalina, O., \& Moffat, D. (2019). Development of digital game environments stimulating creativity in engineering education. Handbook of Research on ..., Query date: 202011-06 05:22:56. https://www.igi-global.com/chapter/development-of-digital-gameenvironments-stimulating-creativity-in-engineering-education/210335

Amabile, T. (2018). Creativity in context: Update to the social psychology of creativity. books.google.com.

Anderson, C., Dalsen, J., Kumar, V., Berland, M., \& ... (n.d.). Thinking skills and creativity. 
Angarita, L., \& Chiappe, A. (2019). Are ICT good partners for the development of creativity? A systematic review of literature. International Journal of Arts and ..., Query date: 2020-11-06 05:22:56. https://www.inderscienceonline.com/doi/abs/10.1504/IJART.2019.100408

Annetta, L. (2013). Cognitive aspects of creativity: Science learning through serious educational games. Teaching Creatively and Teaching Creativity, Query date: 2020-11-29 04:55:43, 53-62. https://doi.org/10.1007/978-1-4614-5185-3_4

Apperley, T., \& Walsh, C. (2012). What digital games and literacy have in common: A heuristic for understanding pupils' gaming literacy: What digital games and literacy have in common. Literacy, 46(3), 115-122. https://doi.org/10.1111/j.1741-4369.2012.00668.x

Arnab, S., Clarke, S., \& Morini, L. (2019). Co-Creativity through Play and Game Design Thinking. Electronic Journal of E-Learning, Query date: 2020-11-06 05:22:56. https://eric.ed.gov/?id=EJ1237285

Arumsari, R., \& Sugiat, M. (2015). Design of Educational Game About Tourism of Bandung for Elementary Students (Bandung Creative Movement 2015 2nd International Conference on Creative .... openlibrary.telkomuniversity.ac.id.

Azizah, N. (2015). The effects of educational card game on students'creativity and conceptual understanding in learning excretory system. repository.upi.edu. http://repository.upi.edu/id/eprint/22828

Behnamnia, N., Kamsin, A., Ismail, M., \& ... (2018). The Main Components of Creativity in Educational Game: A Case Study. ... Conference for Emerging ..., Query date: 2020-11-06 05:22:56. https://link.springer.com/chapter/10.1007/978-3-319-95450-9_25

Boltz, L., Henriksen, D., \& Mishra, P. (2015). Rethinking technology \& creativity in the 21st century: Empathy through gaming-perspective taking in a complex world. TechTrends, Query date: 2020-11-06 05:22:56. http://danah-henriksen.com/wp-content/uploads/2015/11/techtrendsempathy.pdf

Bottino, R. (2012). MAGICAL: Collaborative game building as a means to foster reasoning abilities and creativity. Proceedings of the 12th IEEE International Conference on Advanced Learning Technologies, ICALT 2012, Query date: 2020-11-29 04:55:43, 744-745. https://doi.org/10.1109/ICALT.2012.226

Boyce, A., Doran, K., Campbell, A., Pickford, S., \& ... (2011). Social user generated content's effect on creativity in educational games. ... on Creativity and ..., Query date: 2020-11-06 05:22:56. https://dl.acm.org/doi/abs/10.1145/2069618.2069675

Cascini, G. (2015). OTSM-TRIZ games: Enhancing creativity of engineering students. Procedia Engineering, 131(Query date: 2020-11-29 04:55:43), 711-720. https://doi.org/10.1016/j.proeng.2015.12.360

Chan, Z. (2013). A systematic review of creative thinking/creativity in nursing education. Nurse Education Today, Query date: 2020-11-06 05:22:56. https://www.sciencedirect.com/science/article/pii/S0260691712002870

Connolly, T. M., Boyle, E. A., MacArthur, E., Hainey, T., \& Boyle, J. M. (2012). A systematic literature review of empirical evidence on computer games and serious games. Computers \& Education, 59(2), 661-686. https://doi.org/10.1016/j.compedu.2012.03.004

Davies, D., Jindal-Snape, D., Digby, R., Howe, A., \& ... (2014). The roles and development needs of teachers to promote creativity: A systematic review of literature. Teaching and Teacher ..., $\begin{array}{lll}\text { Query } \quad \text { 2020-11-06 } & \text { 05:22:56. }\end{array}$ https://www.sciencedirect.com/science/article/pii/S0742051X14000274

Emamirizi, C., Haghani, F., \& Yousefy, A. (2019). The study effect of using educational games in the teaching of geometry in achievement and creativity of the female students in third grade. Query date: 2020-11-06 05:22:56. https://www.sid.ir/FileServer/JF/33313986105

Fardilha, F., \& Allen, J. (2020). Defining, assessing, and developing creativity in sport: A systematic narrative review. International Review of Sport and Exercise ..., Query date: 2020-11-06 05:22:56. https://www.tandfonline.com/doi/abs/10.1080/1750984X.2019.1616315 
Fessakis, G. (2015). Could computer games-based problem solving positively affect the development of creativity in young children? A mixed method case study. Young Children and Families in the Information Age: Applications of Technology in Early Childhood, Query date: 2020-11-29 04:55:43, 207-225. https://doi.org/10.1007/978-94-017-9184-7_12

Girard, C., Ecalle, J., \& Magnan, A. (2013). Serious games as new educational tools: How effective are they? A meta-analysis of recent studies: Serious games as educational tools. Journal of Computer Assisted Learning, 29(3), 207-219. https://doi.org/10.1111/j.13652729.2012.00489.x

Gordeeva, I., \& Veryaskina, M. (2019). Development of Professional Creativity of Teachers in the System of Professional Safety Culture of Children in Transport. ... 21st Century from the Positions of ..., Query date: 2020-11-06 05:22:56. https://books.google.com/books?hl=en\&lr=\&id=Wc67DwAAQBAJ\&oi=fnd\&pg=PA446\&dq= educational+game+for+creativity\&ots=G2gomGHfGD\&sig=bzd--h0glmYJRxAg1sIkAIXt7Us

Hacker, M., \& Kiggens, J. (2011). Gaming to learn: A promising approach using educational games to stimulate STEM learning. Fostering Human Development Through ..., Query date: 2020-06-30 21:38:52. https://brill.com/view/book/edcoll/9789460915499/BP000015.xml

Kusmawati, A. (2017). Pengembangan SSP biologi domain kreativitas untuk meningkatkan karakter kreatif, tanggung jawab dan prestasi belajar siswa. Jurnal Inovasi Pendidikan IPA, 3(1), 12. https://doi.org/10.21831/jipi.v3i1.13683

Mishra, P. (2012). Rethinking technology \& creativity in the 21st century: Crayons are the future. TechTrends, Query date: 2020-11-06 05:22:56. https://link.springer.com/content/pdf/10.1007/s11528-012-0594-0.pdf

Pellas, N., Kazanidis, I., Konstantinou, N., \& ... (2017). Exploring the educational potential of threedimensional multi-user virtual worlds for STEM education: A mixed-method systematic literature review. Education and ..., Query date: 2020-06-30 21:38:52. https://link.springer.com/article/10.1007/s10639-016-9537-2

Pinder, P. (2018). First Bahamas Mixed-Methods Game-Based Learning Research Reveals Teachers" Support" Use of Games in STEM Instruction. In Brief Preliminary Findings. Online Submission, Query date: $2020-06-30$ 21:38:52. https://eric.ed.gov/?id=ED582903

Santofani, A., \& Rosana, D. (2016). Pengembangan tes kreativitas pada pembelajaran fisika dengan pendekatan inkuiri pada materi teori kinetik gas. Jurnal Inovasi Pendidikan IPA, 2(2), 134. https://doi.org/10.21831/jipi.v2i2.6373

Sawyer, R. (2017). Teaching creativity in art and design studio classes: A systematic literature review. Educational Research Review, Query date: 2020-11-06 05:22:56. https://www.sciencedirect.com/science/article/pii/S1747938X17300271

Supandi, M., \& Senam, S. (2019). Mengembangkan keterampilan berpikir kritis dengan game ritual tumpe. Jurnal Inovasi Pendidikan IPA, 5(2), 139-146. https://doi.org/10.21831/jipi.v5i2.25920

van Laar, E., van Deursen, A. J. A. M., van Dijk, J. A. G. M., \& de Haan, J. (2017). The relation between 21st-century skills and digital skills: A systematic literature review. Computers in Human Behavior, 72, 577-588. https://doi.org/10.1016/j.chb.2017.03.010

Zaki, Y., Muwali, A. A., \& Mahdi, N. (2018). Infusing Creativity and Technology Through Repurposing Existing Digital Tools and Social Media Apps for Educational Purposes. ... , Game Creation, Design, Learning, and ..., Query date: 2020-11-06 05:22:56. https://link.springer.com/chapter/10.1007/978-3-030-06134-0_36 